\title{
Feasibility Check of Electrification in Istanbul Metrobus Line
}

\author{
Turgay Gucukoglu, Haluk Sari and Koray Erhan \\ Software \& Electronics, AVL Research \& Engineering, Istanbul, Turkey
}

\begin{abstract}
Today, climate change is a significant effect of population growth, especially in big cities. Transport in metropolitan cities is the most important reason for climate change with the contribution of $\mathrm{CO}_{2}$ pollution that threatens human health and the environment. Electrified transport systems can therefore provide a suitable solution to air pollution and health problems. This study investigates feasibility of applying electric buses to Metrobus line in Istanbul. Initially, Metrobus line data regarding to number of vehicles, number of stops, route length is gathered from official Istanbul transportation system to define how much energy is needed for the routes. Then, it is analyzed how to re-charge proposed batteries for allocation of chargers on the stations where is applicable.
\end{abstract}

Keywords-Electric Bus, Metrobus, Electrification analysis

\section{INTRODUCTION}

With the urbanization in the world, the population of the city increases day by day. The increase in population causes serious damage to the city's natural environment and air quality. Public transportation plays a major role in cities to ensure urban sustainability in order to mitigate the effects of population growth. The decision which was initiated by major metropolises to gradually discontinue the purchase of fossil fuel buses has played an important role in zeroemission public transport systems. Moreover, improvements in battery capacities and fast charging systems have enabled many bus companies to expand their production and R\&D (Research and Development) activities in the field of electric buses [1].

The buses used for public transportation can be divided into six types. These are diesel, compressed natural gas $(\mathrm{CNG})$, biofuels, hybrid diesel, hydrogen, and electric bus (e-bus) $[2,3]$. Although diesel buses are the most widely used bus type, hybrid and e-buses are alternative to conventional diesel buses [4]. Furthermore, many of diesel bus manufacturers such as Man, Volvo, Iveco, VDL, and Irizar also manufacture e-buses. E-buses have been used in cities for short routes early on $[\mathbf{5 , 6}]$. Generally, the ranges of e-buses are between 30-300 km and battery capacities change between 76-340 $\mathrm{kWh}$. The range of e-bus depends on some features such as battery capacity, charging methodology, cooling, driving cycle, etc. $[\mathbf{1 , 6 ]}$.

In this study, the case of replacement conventional buses with the e-buses is analyzed in accordance with the obtained data from a Metrobus line in Istanbul, Turkey. In conclusion, it is determined that which line is effective to transform the buses to electrified buses instead of conventional buses. In consideration of the data obtained, it is analyzed on which lines buses can be turned into electric buses.
Metrobus line in Istanbul is the largest compared to similar applications around the world. Accordingly, electrifying such a big transportation line is a huge challenge. In addition, many studies are being carried out on the electrification of this line in Turkey. The results obtained here will serve as an example for similar applications in the world. In this context, relevant additions have been made to the study.

\section{E-BUS}

There has been a significant increase in e-bus production worldwide in recent years. In the European region, e-bus production accounts for $9 \%$ of global production. The size of e-bus fleet in European region and the USA is given in Fig. 1.

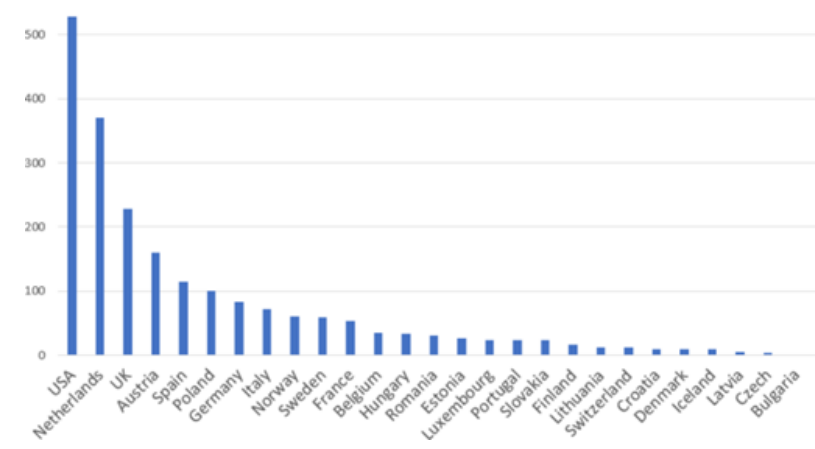

Fig. 1. The size of e-bus fleet in European region and USA [7].

Currently, the e-bus production leader in the world is China. There are currently 400,000 e-buses used in China. China accounts for $90 \%$ of the electric bus production in the world and $75 \%$ of the batteries of these electric buses in the world. LFP (Lithium Iron Phosphate $\left(\mathrm{LiFePO}_{4}\right)$ ) batteries are used more than \%97 in e-buses [8]. Distribution of estimated bus market share in 2020 is given in Fig. 2.

In Turkey, the first electric bus was used in Konya in 2016 for public transportation. At the beginning of 2017, it was announced that 200 electric buses will be bought by IETT (Istanbul Electric Tram and Tunnel Operations) in Istanbul. The first e-bus domestic production was done by Bozankaya. With E-Karat, Turkey has gone into producing electric buses [9]. The other e-bus manufacturer except Bozankaya are Otokar, Karsan, BMC, and TEMSA in Turkey [10]. E-bus manufacturers in Turkey is given in Fig. 3.

E-buses differ in themselves in many ways, such as energy source type, charging strategy, charging refueling interface, on-board energy source, drive motor, drive topology, cooling and heating. 


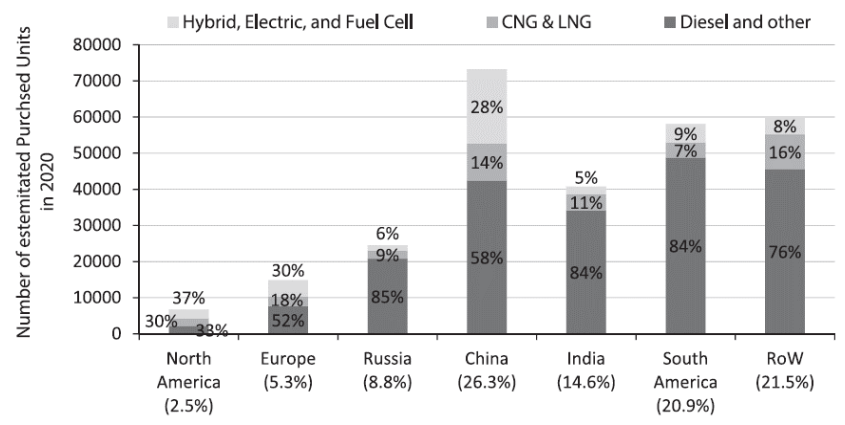

Fig. 2. Distribution of estimated bus market share in 2020 [10].

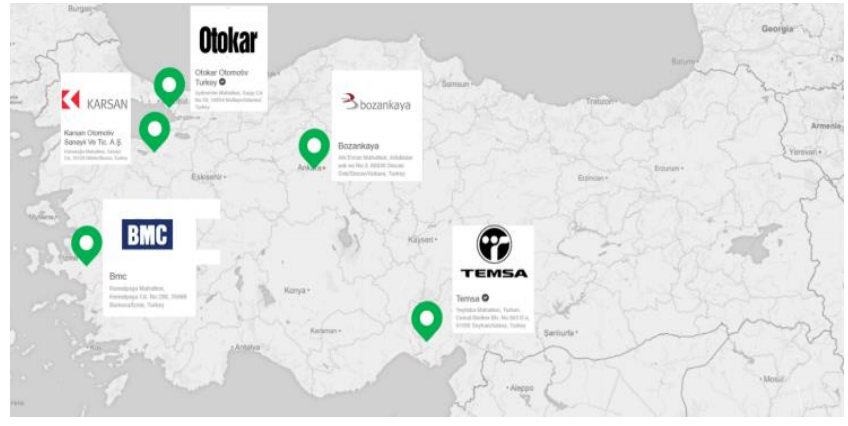

Fig. 3. E-bus manufacturers in Turkey [11].

LFP, NMC (Lithium Nickel Manganese Cobalt Oxide $(\mathrm{LiNiMnCoO} 2))$, and LTO (Lithium Titanite $\left.\left(\mathrm{Li}_{2} \mathrm{TiO}_{3}\right)\right)$ are generally preferred as battery chemistry in electric buses. In addition to battery technology, it is used as a power source in addition to the battery in fuel cells and supercapacitors. Rails, low, medium and high voltage are used in addition to the built-in battery and $\mathrm{H}_{2}$ tank to provide the necessary power to the electric buses. Opportunity, in motion, and depot are charging strategies used in e-bus. Manual, pantograph, induction, trolleybus current collector, and battery swapping methods are used to charge the battery. The most common types of electric motors used in electric buses are permanent magnet synchronous, electrically excited synchronous, asynchronous, and switched reluctance and central motor, and wheel hub motor are used as drive topologies. Body type of e-buses can be divided into 4 as $12 \mathrm{~m}$ single-deck, $18 \mathrm{~m}$ single-deck, $24 \mathrm{~m}$ bi-articulated and double-deck. Electric air-conditioning is used as a cooling system and electric resistance heating, electric heat pump, and fuel heating are preferred heating systems in e-buses [12].
According to UNECE (United Nations Economic Commission for Europe) regulations, there are vehicle categories which classify a land vehicle for regulatory purposes. In that categorization, $M$ class is defined as 'Vehicles having at least four wheels and used for the carriage of passengers (e.g., standard car with 2, 3, 4 doors).' M class vehicles are also spread into 3 categories as M1, M2 and M3 which is directly referring to buses with the definition as 'Vehicles used for the carriage of passengers, comprising more than eight seats in addition to the driver's seat, and having a maximum mass exceeding 5 tones' [13].

The buses may also be categorized according to different specifications. Single decker, articulated, coach, midi-bus, mini-bus and double decker buses can be a categorization according to different use-cases while low floor, low entry and high floor buses can be another category according to design criteria. In this study, further specifications are evaluated regarding articulated class bus. Electrification feasibility of Metrobus line in Istanbul/Turkey is studied in the next sections.

\section{Proposed E-bus concept for metrobus}

The metrobus line where the study is carried out is in Istanbul. This metrobus line operates intercontinental and main target is to reduce traffic jam between crowded centers. With the capacity to carry 950,000 passengers per day, it is the largest among its kind in the world [14]. There are 8 lines on the Metrobus route with 44 stations. The first and last stops of each of these lines are different. In addition, the number of buses operating on each line varies daily. Table I shows the numerical data of the metrobus line. There is a total of 495 buses moving along the line. These buses are grouped for each line. The distance covered for the shortest line is $11 \mathrm{~km}$ and the distance covered for the longest line is $52 \mathrm{~km}$. Line and route information for each line is given in Table II. Route map is also seen in Figure 4.

When calculating the required battery capacity values, it is considered that a bus has the capacity to cover the longest line twice. The energy consumption value is $250 \mathrm{kWh} / 100 \mathrm{~km}$ for the 19.725-meter bus and $239 \mathrm{kWh} / 100 \mathrm{~km}$ for the 18.125-meter bus respectively. These consumption values are calculated by considering vehicle dynamics such as air drag force, rolling resistance, gear box loses, axle loses, etc.

TABLE I

METROBUS LINE GENERAL DATA

\begin{tabular}{|c|c|c|c|c|c|c|c|}
\hline $\begin{array}{l}\text { Route } \\
\text { Number }\end{array}$ & $\begin{array}{l}\text { Number of } \\
\text { vehicles }\end{array}$ & $\begin{array}{l}\text { Turnaround time } \\
\text { (one cycle) }\end{array}$ & $\begin{array}{l}\text { Track length } \\
(\mathrm{km})\end{array}$ & $\begin{array}{l}\text { Number } \\
\text { of stops }\end{array}$ & $\begin{array}{l}\text { Average vehicle } \\
\text { speed }(\mathrm{km} / \mathrm{h})\end{array}$ & $\begin{array}{l}\text { Average turnaround } \\
\text { time }(\mathrm{s})\end{array}$ & $\begin{array}{lll}\text { Total range per } \\
\text { vehicle }(\mathrm{km})\end{array}$ \\
\hline 34 & 92 & 125 & 30 & 27 & 34 & 82 & 423 \\
\hline $34 \mathrm{~A}$ & 22 & 94 & 22 & 20 & 30 & 256 & 88 \\
\hline $34 \mathrm{AS}$ & 100 & 162 & 41.5 & 35 & 31 & 97 & 493 \\
\hline $34 \mathrm{BZ}$ & 128 & 154 & 40 & 39 & 31 & 72 & 562 \\
\hline $34 \mathrm{C}$ & 70 & 115 & 29 & 26 & 35 & 99 & 361 \\
\hline $34 \mathrm{G}$ & 15 & 180 & 52 & 44 & 35 & 720 & 260 \\
\hline $34 \mathrm{U}$ & 38 & 40 & 11 & 6 & 38 & 63 & 32 \\
\hline $34 Z$ & 30 & 52 & 11.5 & 8 & 31 & 104 & 700 \\
\hline Total & 495 & $\mathrm{~N} / \mathrm{A}$ & $\mathrm{N} / \mathrm{A}$ & $\mathrm{N} / \mathrm{A}$ & $\mathrm{N} / \mathrm{A}$ & $\mathrm{N} / \mathrm{A}$ & $\mathrm{N} / \mathrm{A}$ \\
\hline
\end{tabular}


TABLE II

ROUTE FOR EACH METROBUS LINE
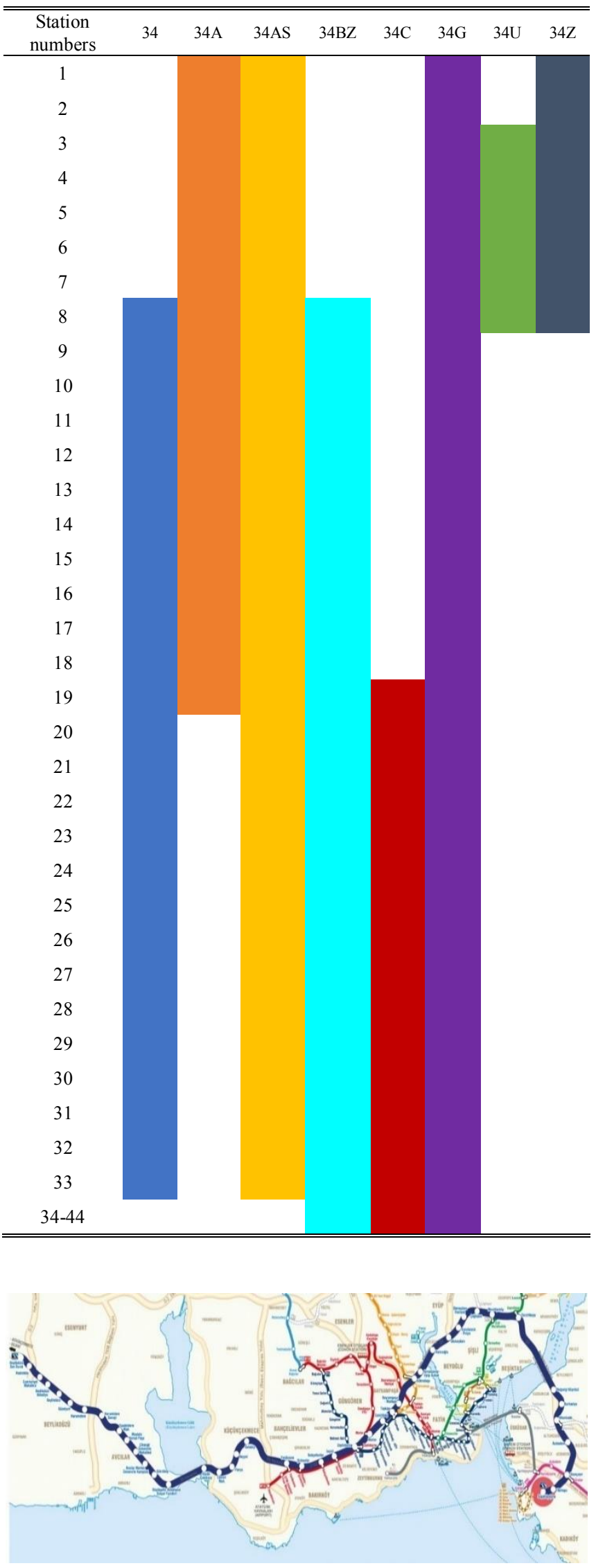

Fig. 4. Metrobus line route on the map (blue line)
In the analyses, energy consumption value which is greater than the other is taken into consideration. One of the advantages of this is the production-based price advantage of using one type of battery. Figure 5 gives percentage of energy losses due to vehicle dynamics and auxiliary loads.

Detailed consumption data for buses is shown in Table III. In the calculations, the average speed value of the buses is taken as $40 \mathrm{~km} / \mathrm{h} \mathrm{[15]}$. The passenger carrying capacity of buses is a factor affecting on total weight. Both buses can carry a total of 160 passengers. In the calculations, the average occupancy rate is taken as $60 \%$ using with official data (IETT).



Fig. 5. Energy losses rates

The energy and power densities of the battery packs used in electric buses play important role which directly effects on vehicle range. Battery design should be made by considering the weight of the buses and the constant carrying of passengers throughout the day as it requires full time operation during a day. In this type of application, battery system is requested to deliver high number of cycles in demand. That demand is provided by LFP type cell which is suitable for high cycle life-time. Accordingly, the average number of cycles is assumed as 6000. The energy consumption values of buses carrying passengers on each line is given in Table IV. The total desired energy value plays important role in determining the battery capacity of buses. 
Required energy for buses to make two cycles on the longest line $(52 \mathrm{~km})$ is approximately $520 \mathrm{kWh}$. However, this value is the usable energy required by bus. Batteries should not charge and discharge between $0 \%$ and $100 \%$ SoC (State of Charge) values. At that point, the concept of SoC window is defined. The energy value is given in here represents usable energy. SoC window value was determined as 5-92\% in order to extend the life of the batteries. In this case, installed battery capacity value is calculated as $600 \mathrm{kWh}$.

According to the energy values obtained in Table IV, daily charge per vehicle is calculated in Table V. The purpose of this calculation is to determine how many times a day the bus with $600 \mathrm{kWh}$ battery capacity needs to be charged. Calculations are made separately for all lines.

According to obtained data, buses operating on line 34 should be charged 187 times a day. Considering buses that start to operate in this line, each bus needs to be charged about 2 times a day. These values are given in Table $\mathrm{V}$ for each line code. Total desired Bus/Charge number for all metrobus line is 1026. This value indicates that total chargers installed along the line should charge 1026 vehicles per day. A bus with a $600-\mathrm{kWh}$ battery capacity will charge between 3 and 6 hours as average. When a vehicle's charging time is assumed to be approximately 4 hours, a charger can charge 6 battery packs in 24 hours. That means 1026 vehicle batteries can be recharged for approximately 24 hours of continuous operation by approximately 171 chargers. On the Metrobus line, there are five stations where buses can be parked for required charging time. Referred station numbers are 1, 8, 19, 33 and 44. Therefore, chargers shall be in those 5 stops. However, it is not possible to install those number of chargers due to limited space in the stations located in city centre.

When the places that are suitable for charging stations are examined, it is not possible to place more than 50 chargers in total considering available bus parking lot. Based on these results, it is possible to charge a total of $300-350$ buses in 24 hours. This is equal to approximately $30-35 \%$ of the total number of buses. With this assumption, the lines which are suitable for the operation of electric buses are shown in green in the column of daily vehicle / charge number in Table V. Lines that are not applicable for electrification are marked with red.

On the other hand, battery lifetime is also assessed. Maximum charge-discharge cycle of applied cells is assumed as 6000. Based on these values, battery lifetime of buses operating in each line is given in Table V. Battery lifetime which is less than $7-8$ years is not effective compared to internal combustion engine in terms of TCO (Total Cost Ownership).

TABLE III

REQUIRED ENERGY VALUES FOR E-BUSES

Required energy content for 2 cycle on the longest route $34 \mathrm{G}$

\begin{tabular}{ccccc}
\hline Model & Average energy consumption & Required energy content & Unit & Selected energy content \\
Citaro & $\mathbf{2 3 9 k W h / 1 0 0 k m}$ & $\mathbf{4 9 6 . 6 9}$ & $\mathrm{kWh}$ & $\mathbf{6 0 0}$ \\
Capacity & $\mathbf{2 5 0 k W h} / \mathbf{1 0 0 k m}$ & $\mathbf{5 1 9 . 7 7}$ & $\mathrm{kWh}$ & $\mathbf{6 0 0}$ \\
\hline \hline
\end{tabular}

TABLE IV

ENERGY CONSUMPTION VALUES FOR ONE CYCLE

\begin{tabular}{cccccccccc}
\hline \hline Route & $->$ & 34 & $34 \mathrm{~A}$ & $34 \mathrm{AS}$ & $34 \mathrm{BZ}$ & $34 \mathrm{C}$ & $34 \mathrm{G}$ & $34 \mathrm{U}$ & $34 \mathrm{Z}$ \\
\hline Distance $(\mathrm{km})$ & $->$ & 30 & 22 & 41.5 & 40 & 29 & 52 & 11 & 11.5 \\
Energy consumption $(\mathrm{kWh})$ & Citaro & $\mathbf{7 1 . 6}$ & $\mathbf{5 2 . 5}$ & $\mathbf{9 9 . 1}$ & $\mathbf{9 5 . 5}$ & $\mathbf{6 9 . 2}$ & $\mathbf{1 2 4 . 2}$ & $\mathbf{2 6 . 3}$ & $\mathbf{2 7 . 5}$ \\
Energy consumption $(\mathrm{kWh})$ & Capacity & $\mathbf{7 5 . 0}$ & $\mathbf{5 5 . 0}$ & $\mathbf{1 0 3 . 7}$ & $\mathbf{1 0 0 . 0}$ & $\mathbf{7 2 . 5}$ & $\mathbf{1 2 9 . 9}$ & $\mathbf{2 7 . 5}$ & $\mathbf{2 8 . 7}$ \\
\hline \hline
\end{tabular}

TABLE V

NUMBER OF DAILY CHARGES PER LINE

\begin{tabular}{|c|c|c|c|c|c|c|c|}
\hline $\begin{array}{l}\text { Line } \\
\text { Route }\end{array}$ & $\begin{array}{l}\text { Number of daily } \\
\text { bus trips }\end{array}$ & $\begin{array}{l}\text { Trips per } \\
\text { bus }\end{array}$ & $\begin{array}{l}\text { Number of daily } \\
\text { charges }\end{array}$ & $\begin{array}{l}\text { Total bus/charge } \\
\text { number }\end{array}$ & $\begin{array}{l}\text { Battery } \\
\text { EOL (years) }\end{array}$ & $\begin{array}{l}\text { Feasibility } \\
\text { for e-Bus }\end{array}$ & Required Charger \\
\hline 34 & 1296 & 14 & 2.03 & 187 & 8 & + & 187 \\
\hline $34 \mathrm{~A}$ & 88 & 4 & 0.42 & 9 & 39 & + & 9 \\
\hline $34 \mathrm{AS}$ & 1188 & 12 & 2.37 & 237 & 7 & - & - \\
\hline $34 \mathrm{BZ}$ & 1798 & 14 & 2.70 & 346 & 6 & - & - \\
\hline $34 \mathrm{C}$ & 872 & 12 & 1.74 & 122 & 9 & + & 122 \\
\hline $34 \mathrm{G}$ & 75 & 5 & 1.25 & 19 & 13 & + & 19 \\
\hline $34 \mathrm{U}$ & 110 & 3 & 0.15 & 6 & 110 & + & 6 \\
\hline $34 \mathrm{Z}$ & 1827 & 61 & 3.37 & 101 & 5 & - & - \\
\hline Total & N/A & N/A & N/A & 1026 & N/A & N/A & 343 \\
\hline
\end{tabular}


According to that assumption, green lines in the Battery EOL (End of Life) column in Table $\mathrm{V}$ are compatible with electrification and the red marked lines are not feasible. When both columns (Total bus/charge number and Battery EOL) are examined together, it is seen that 5 lines $(34,34 \mathrm{~A}, 34 \mathrm{C}$, $34 \mathrm{G}, 34 \mathrm{U})$ are suitable for electrical conversion of transportation.

\section{CONCLUSION}

Today, demand for electric vehicles is limited by the introduction of some parameters. In this context, the cost of batteries is fundamental, especially in commercial vehicles that are constantly in use. With the decrease in battery costs in the following years, demand for electric vehicles is expected to increase.

When the results obtained in this study are reviewed, operating time (distance) is very important especially in electric bus applications. Electric bus is not advantageous in terms of TCO value, since operating distance is above a certain value, especially as the battery life ends very quickly.

As a result, obtained values in the study are considered and it is not possible to completely electrify the Metrobus line. However, in order to reduce emission values, it is reasonable to convert some routes to electric buses.

For future studies, the feasibility study shall be performed in order to re-charge the batteries on all buses. Initially, the whole transportation system should be designed so that the operation of the electric buses can be carried out. As an example, the charging station network infrastructure should be installed and the parking spaces where buses can wait while charging should be considered.

Taking everything into account, the problem could be focus on optimization techniques and linear programming to determine the electric buses recharging scheduling for a transportation network in Istanbul/TURKEY.

\section{REFERENCES}

[1] Yilmaz, C. (2018). Economic Evaluation of Urban Electric Bus Charge Stations: Case of Eindhoven, The Netherlands. MSc Thesis, Istanbul Technical University, Graduate School of Natural and Applied Sciences, Istanbul.

[2] Alves, B. B., Sethi, K., Dodero, A. L., Guerrero, A. H., Puga, D. Yeghyaian, E., Bose, R. (2019). Green Your Bus Ride: Clean Buses in Latin America (No. 133929).

[3] "Maria XYLIA, Towards electrified public bus transport: The case of Stockholm Doctoral thesis, KTH Royal Institute of Technology Industrial Engineering and Management Department of Energy Technology Energy and Climate Studies, Stockholm, Sweden, 2018."

[4] Göhlich, D., Kunith, A., \& Ly, T. (2014). Technology assessment of an electric urban bus system for Berlin. WIT Trans. Built Environ, 138, 137-149.

[5] Lajunen, A., \& Lipman, T. (2016). Lifecycle cost assessment and carbon dioxide emissions of diesel, natural gas, hybrid electric, fuel cell hybrid and electric transit buses. Energy, 106, 329-342.

[6] Teoh, L.E., Khoo, H.L., Goh, S.Y., Chong, L.M., (2018). Scenariobased electric bus operation: A case study of Putrajaya, Malaysia. Int. J. Transp. Sci. Technol, 7, pp. 10-25.

[7] Houbbadi, A., Pelissier, S., Trigui, R., Redondo-Iglesias, E., \& Bouton, T. (2019, May). Overview of Electric Buses deployment and its challenges related to the charging-the case study of TRANSDEV.

[8] De-Leon, S., E-Bus Battery Market 2019. https://www.emove360.com/wp-content/uploads/2019/10/E-BusBattery-Market-2019.pdf, date of access: 24.12.2019
[9] Mahmoud, M., Garnett, R., Ferguson, M., \& Kanaroglou, P. (2016). Electric buses: A review of alternative powertrains. Renewable and Sustainable Energy Reviews, 62, 673-684.

[10] https://zeeus.eu/uploads/publications/documents/zeeus-ebus-report2.pdf, date of access: 11.11.2019

[11] EVTrader, https://evtrader.com/c/electric-bus-manufacturers/, date of access: 24.12.2019

[12] Göhlich, D., Fay, T. A., Jefferies, D., Lauth, E., Kunith, A., \& Zhang, X. (2018). Design of urban electric bus systems. Design Science, 4.

[13] UNECE TRANS/WP.29/1045 - Special Resolution No. 1

[14] https://www.iett.istanbul/tr/main/pages/tarihce/2, date of access: 22.12.2019

[15] https://www.iett.istanbul/tr/main/hatlar/, date of access: 22.12.2019

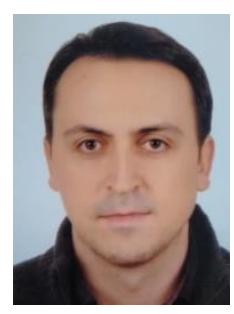

Turgay Gucukoglu was born in 1988 in Kahramanmaras/Turkey. He received his BSc in Electrical Engineering from Yildiz Technical University (YTU), Turkey in 2011. Then, he completed his MSc in Control and Automation Engineering at Yildiz Technical University in 2019.He is currently holding position of Senior Battery Development Engineer in the field of Battery Systems at AVL R\&D Company, Turkey. He has published 1 paper about battery systems for electric \& hybrid electric vehicles.

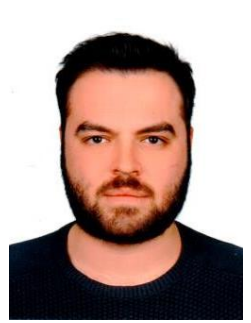

Haluk Sar1 was born in 1988 in Kirklareli/TURKEY. He graduated as an Automotive Engineer from Ruse "Angel Kanchev" University, Bulgaria in 2012. He has 6 year-experience in field of $\mathrm{xEV}$ Powertrain and Battery Systems. He is currently holding position of Battery Development Engineer at AVL R\&D Company, Turkey.

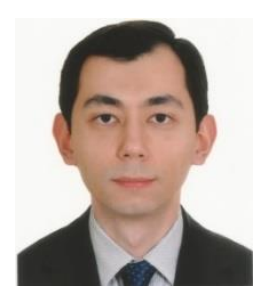

Koray ERHAN was born in 1987 in Turkey. $\mathrm{He}$ received his B.Sc. in Electrical Engineering from Yildiz Technical University, Turkey in 2010. Then he completed his MSc in Electrical Engineering at Istanbul Technical University in 2013. Finally, he got his $\mathrm{PhD}$ at Department of Energy Systems Engineering, Kocaeli University in 2018. He became a research assistant in 2010 at Istanbul Technical University and in 2013 at Kocaeli University. He has published more than 30 papers in different subjects including electric \& hybrid electric vehicles photovoltaic power generation systems, renewable energy sources, energy storage technologies, and smart grid integration and automation systems. He has been a referee in SCI and other indexed journals. He is currently holding position of Battery Development Engineer at AVL R\&D Company, Turkey. 